\title{
THE IMPACT OF CORPORATE SOCIAL RESPONSIBILITY (CSR) ON CUSTOMER LOYALTY: A BIBLIOMETRIC ANALYSIS BETWEEN 2009-2020
}

\author{
Fatima Ezzahra Jiddi ${ }^{1}$ \\ ${ }^{1} \mathrm{PhD}$ Researcher, \\ Laboratory of Scientific Engineering of \\ Organizations (ISO), \\ National School of Business and Management \\ (ENCG-Casa), \\ University Hassan II, 2725 Ain Sebaâ, Casablanca \\ - Morocco.
}

\author{
Abdelmajid Ibenrissoul ${ }^{2}$ \\ ${ }^{2}$ Professor, \\ National School of Business and Management \\ (ENCG-Casa), \\ University Hassan II, 2725 Ain Sebaâ, \\ Casablanca - Morocco.
}

Article DOI: https://doi.org/10.36713/epra5575

\begin{abstract}
Customer loyalty has a noticeable impact on the long-term health of businesses. Hence, with the rise of consumers' awareness, corporate social responsibility (CSR) is essential in consumer behavior, specifically in attracting and retaining customers. This paper try to explore the link between corporate social responsibility (CSR) and customer loyalty based on a bibliometric analysis of 56 indexed articles between 2009 and 2020. First, the leading journals and countries in the field were identified. Subsequently, a citation analysis coupled with content analysis of the 16 most cited articles was performed. The challenge was to find out the clusters' divergence in a pinpointed topic. Accordingly, two main research streams were identified based on their mediating variables: (1) mediating effects related to consumer behavior; (2) mediating effects related to the brand. For future researchers, a future agenda was retrieved from the most influential and recent papers in the field to contribute to advancing the existing knowledge.
\end{abstract}

KEYWORDS: Corporate Social Responsibility, Customer Loyalty, Literature Review, Bibliometric Analysis, Content Analysis.

\section{INTRODUCTION}

In the existing context of the COVID-19 pandemic, businesses are becoming challenged with gaining customers' confidence. Companies learned now more than ever before the importance of retaining their customers and its impact on their businesses' long-term health. The shift in consumer behavior is tremendous. Customer demand was reconsidered and changed from discretionary products and services to essential ones. In the same way, customers started to require ethical and philanthropic actions toward the community over the price. However, socially responsible companies significantly start to overcome the profound crisis. The use of CSR actions is nowadays a promising path toward customer loyalty.

Considering that customer loyalty directly impacts companies' profits (Edvardsson et al. 2000) and that CSR actions impact customer loyalty and purchase intentions (Sen et al. 2006), it is, therefore, crucial to confirm it through previous studies. CSR and customer loyalty are critical issues in the literature, as CSR actions are incredibly beneficial for companies (Palacios-Florencio et al.,2018). In this context, a need to compile the literature on this topic systematically is required. This paper aims to analyze thoroughly the highly reviewed scientific articles regarding the relationship between CSR and customer loyalty.

A bibliometric review based on a literature analysis of 11 years (See Figure 1) addresses the subsequent questions: (1) What are the most influential journals and countries that address this topic? (2) What are the main clusters in the literature of CSR and customer loyalty? (3) What are the relevant future research questions extracted from the influential and trending articles in the literature? 
Consequently, to answer the research questions, this paper is organized in three main sections: section 1

DESCRIPTIVE ANALYSIS' for influential aspects of the literature, section 2 'CLUSTER ANALYSIS' for the quali-quantitative analysis of research streams. Finally, section 3, 'FUTURE RESEARCH AGENDA' to shed new light on future researcher
Figure 1 shows that the most influential articles were published in 2013 and 2015 and that the peak in terms of publications was in 2017 and 2019, with 11 articles each year.

\section{Figure 1: Evolution of the number of publications and citations}

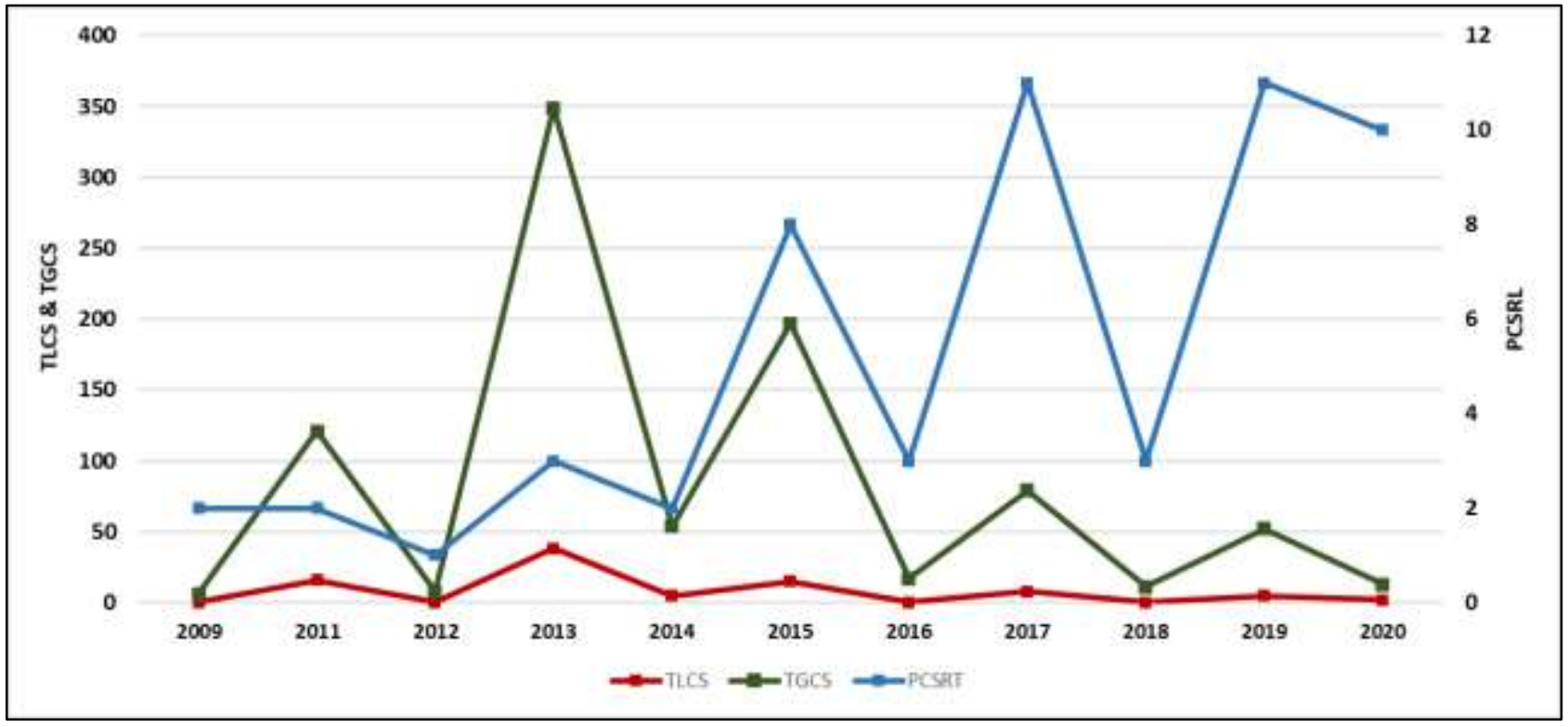

Table 1: Terminology used in this paper

\begin{tabular}{ll}
\hline Term & Explanation \\
\hline PCSRL & $\begin{array}{l}\text { The number of articles on CSR and customer loyalty in our bibliometric } \\
\text { research. }\end{array}$ \\
TLCS & $\begin{array}{l}\text { Total Local Citations Score is the number of times a paper is cited by other } \\
\text { papers within the sample (56). }\end{array}$ \\
TGCS & $\begin{array}{l}\text { Total Global Citations Score is the number of times a paper is cited by other } \\
\text { papers in the whole WoS database. }\end{array}$ \\
\hline
\end{tabular}

\section{METHODOLOGY}

Figure 2 summarizes the methodology used in this paper. 


\section{Figure 2. Research Methodology}

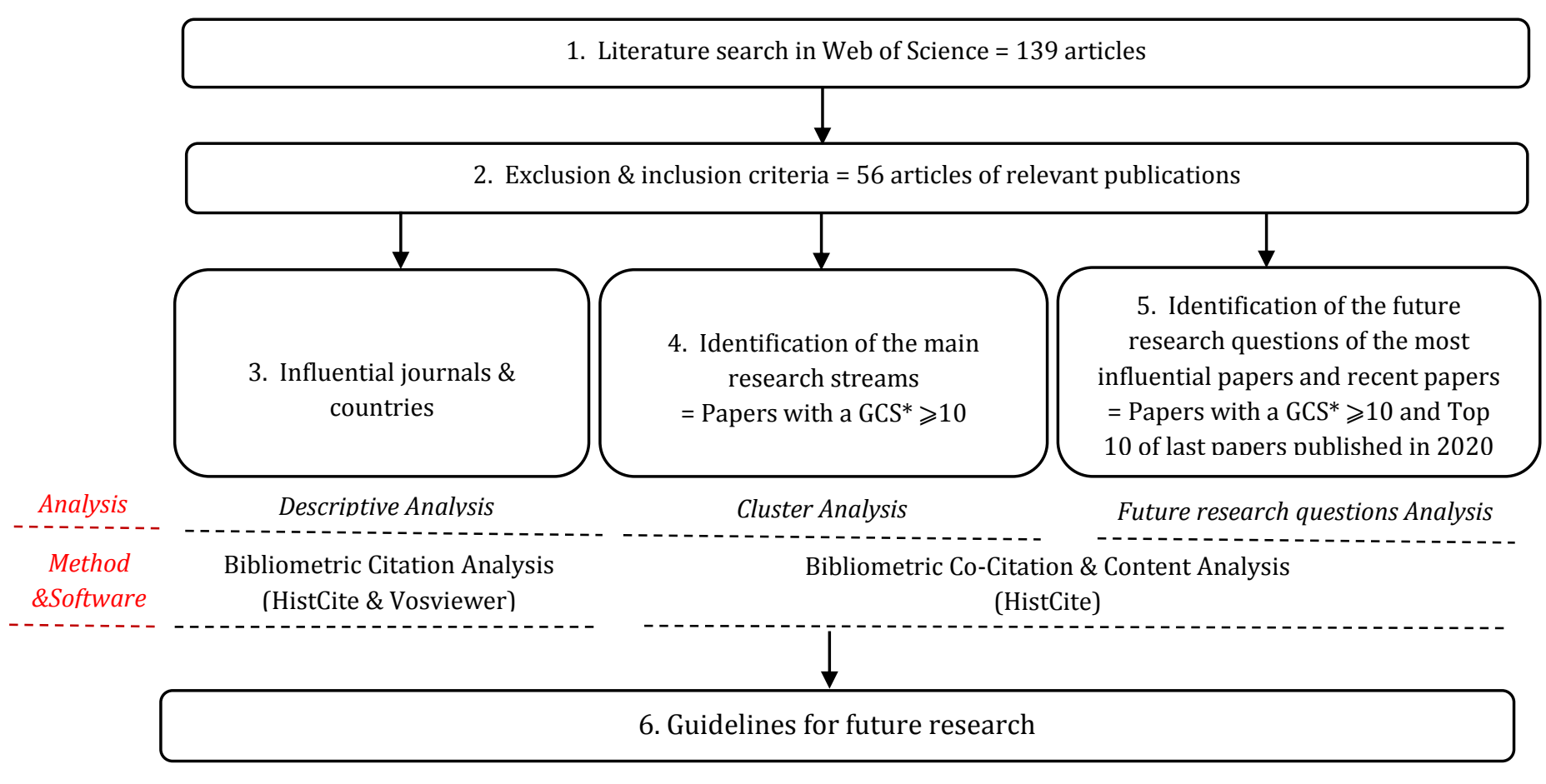

* For more details about LCS and GCS see

\subsection{Data collection method}

The research was done on ISI Web of Science, a highquality database that covers 161 million records and 34,000 indexed journals, according to Clarivate's official website. Our study used Web of Science Core Collection, where cited references for all publications are indexed. To identify only the relevant papers, our search strategy was based on a structured data collection method consisting of both exclusion and inclusion criteria.

The search process used a three-step rigorous approach:

- The search in the 'topic' section, including titles of articles, their abstracts, and keywords, was defined by two keywords' Corporate social responsibility' and 'Customer loyalty' (139). It was then restricted to only scientific articles written in English (118).

- The research areas were limited to 'Business Economics' and 'Social sciences, other topics' Business Economics and Environmental (95).

- To keep the study focused, the search was explicitly limited to CSR rather than related terms such as sustainable development. In addition to that, we excluded articles referring to only one component of CSR, like philanthropy. The data collected was then analyzed by reviewing the Titles, Abstracts, and Keywords (56). The papers were then collected and extracted for bibliometric analysis.

\subsection{Data collection analysis}

The literature review has an essential role in scientific research. It aims at synthesizing literature relevant to a specific research question by producing a qualitative appraisal. Identifying the research streams of CSR can be performed using a bibliometric analysis (Lulewicz-Sas, 2017). Accordingly, a bibliometric analysis and content analysis was carried out. Bibliometric analysis is a statistical analysis based on the quantitative analysis of scientific publications. In the DESCRIPTIVE ANALYSIS' section, we used citation analysis to identify the most influential journals in the field and the papers' countries of origin. The citation analysis is a significant indicator used to measure a publication's influence by other scientific productions. For the 'CLUSTER ANALYSIS' section, we combined a citation analysis with content analysis. A content analysis gathers co-occurrences and coabsences keywords and thus identify fundamental themes (Ronda-Pupo and Guerras-Martin, 2012). A content analysis was carried out for the last section, ' FUTURE RESEARCH AGENDA.' We opted for Vosviewer and HistCite software to visualize and process the data. 


\section{DESCRIPTIVE ANALYSIS \\ 3.1. Influential journals}

Table 2: Journals outlets

\begin{tabular}{|c|c|c|c|c|c|c|}
\hline Ranl & Journals 1 & PCSRT & $\begin{array}{r}\% \text { of tota } \\
\text { publicatiol } \\
s\end{array}$ & Journals 2 & TLCS & TLCS/t \\
\hline 1 & $\begin{array}{l}\text { Social responsibility } \\
\text { journal }\end{array}$ & 14 & 259 & Journal of services marketing & 34 & 4.18 \\
\hline 2 & Sustainability & 12 & 219 & $\begin{array}{l}\text { International journal of } \\
\text { hospitality management }\end{array}$ & 28 & 3.5 \\
\hline 3 & $\begin{array}{l}\text { Cogent business \& } \\
\text { Management }\end{array}$ & 11 & 209 & Journal of business ethics & 5 & 2.83 \\
\hline 4 & Journal of business ethics & 10 & 189 & Social responsibility journal & 5 & 1.25 \\
\hline 5 & $\begin{array}{l}\text { Journal of services } \\
\text { marketing }\end{array}$ & 9 & 169 & Service industries journal & 4 & 0.57 \\
\hline 6 & $\begin{array}{l}\text { Corporate social } \\
\text { responsibility and } \\
\text { environmental } \\
\text { management }\end{array}$ & 7 & 139 & $\begin{array}{l}\text { Asia pacific journal of } \\
\text { marketing and logistics }\end{array}$ & 2 & 1 \\
\hline 7 & $\begin{array}{l}\text { Social behaviour and } \\
\text { personality }\end{array}$ & 5 & $9 \%$ & $\begin{array}{l}\text { Corporate social } \\
\text { responsibility and } \\
\text { environmental management }\end{array}$ & 2 & 0.33 \\
\hline
\end{tabular}

The analysis of the journal outlets was represented in two different categories, according to the PCSRL andTLCS. These measures show the journal focus and influential journals on the research.

As given in Table 2, the most productive (PCSRL) and impactful journals (TLCS) are social responsibility journal, journal of business ethics, journal of services marketing, corporate social responsibility, and environmental management. Within the 42 journals analyzed, various areas discuss the topic, which shows the interdisciplinarity of the field (i.e., management, psychology, marketing). Also, this indicates that the research has been tested in different sectors. 


\subsection{Countries}

Figure 3: Citation network of author's countries

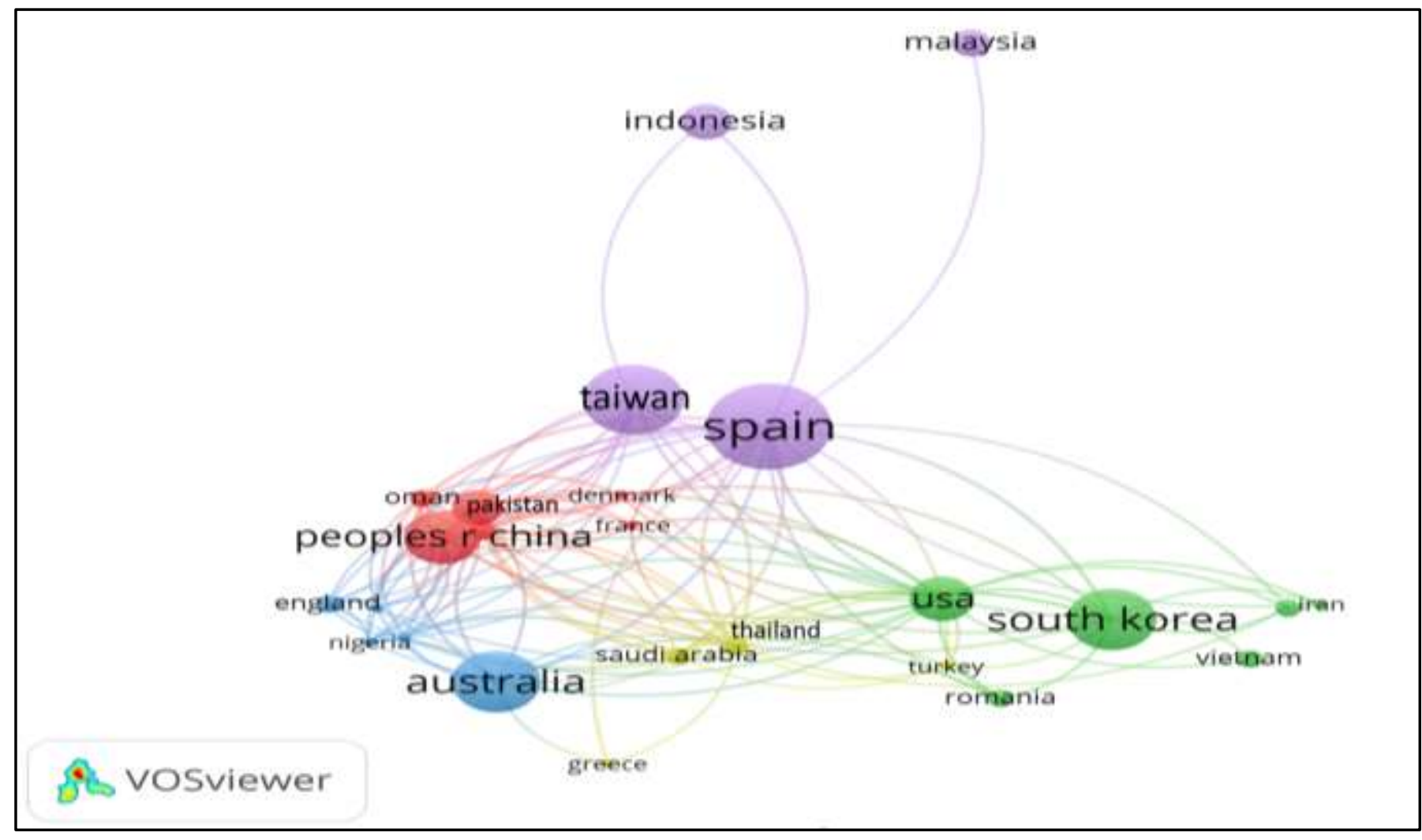

Figure 3 reveals the countries that stand out in terms of production in CSR and customer loyalty literature. The most productive countries are Spain, Taiwan, Australia, South Korea, China, and the USA. This is understandable given the importance of CSR in those countries.

Our results cast a new light on developing countries like Pakistan, Iran, Nigeria, Oman, and Saudi Arabia. Azmat and Ha (2013) stated that developing nations are home to almost half of the world's consumers. The developing nations reveal the emergence of a new significant interest in CSR and its impact on customer loyalty. This shows that customers in developing countries are becoming more aware of their rights than before. This trend is now becoming a challenge for companies to establish a CSR strategy within the core of their business. 


\section{CLUSTER ANALYSIS}

Figure 4: Citation mapping of the most influential articles in the field

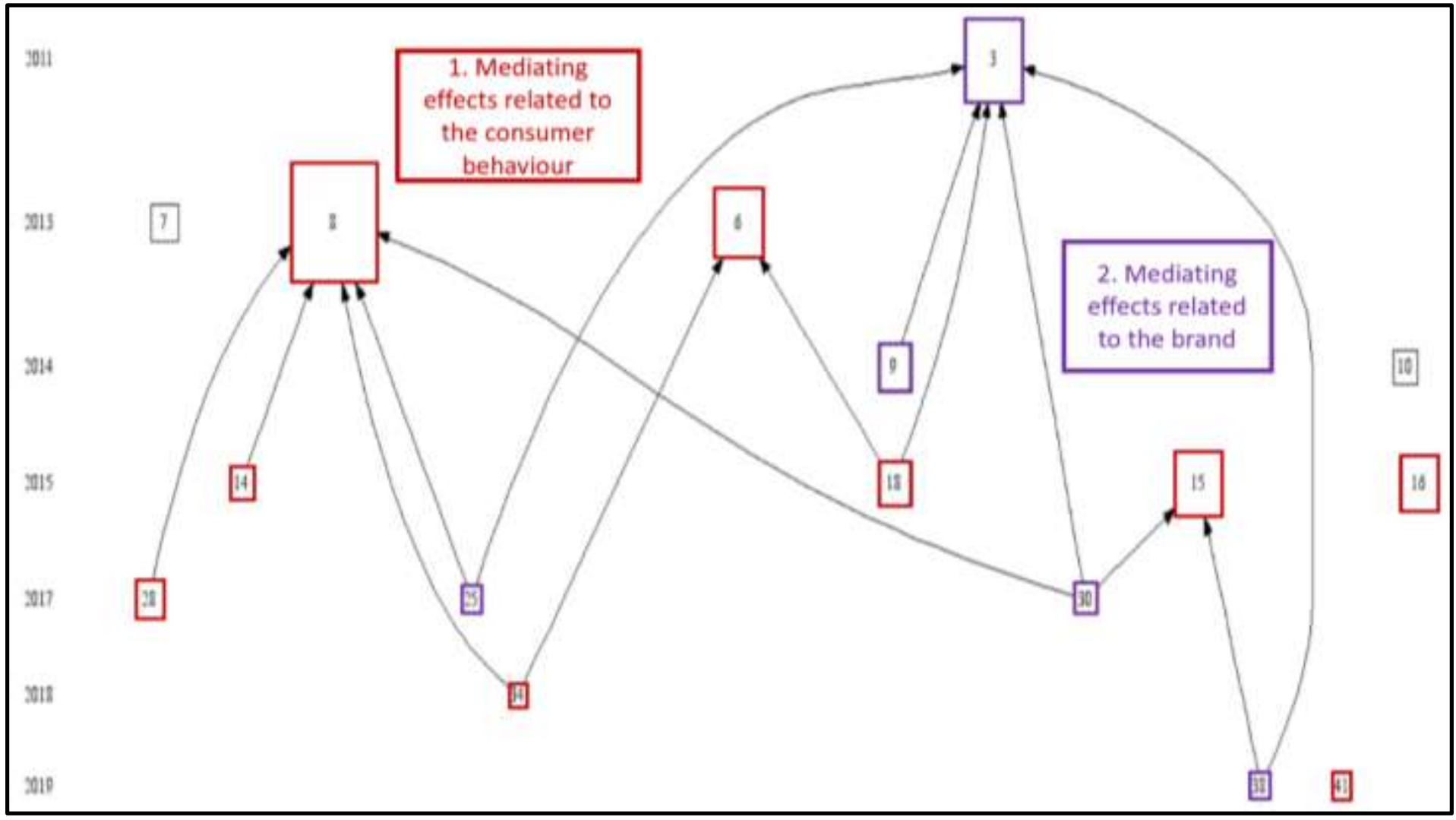

Note: Cluster 1: Mediating effects related to consumer behavior (Article Identification): (8). Martinez and del Bosque (2013), (14). Yeh (2015), (28). Inoue et al., (2017), (34). Palacios-Florencio et al., (2018), (6). Choi and La (2013), (18). Shin and Thai (2014), (15). Pérez and del Bosque (2015), (41). Li et al., (2019), (16). Pérez and del Bosque (2014). Cluster 2: Mediating effects related to the brand (Article Identification): (3). Mandhachitara and Poolthong (2011), (9). Liu et al., (2014), (25). Gürlek et al., (2017), (30). Chang and Yeh (2017), (38). Aramburu and Pescador (2017).

As given in Figure 4, the 'Graph Maker' tool of HistCite allows us to produce a mapping that reveals the way articles refer or build on to each other. The most influential contributions (leading papers with at least a score of 10 global citations (GCS $\geqslant 10$ ) of the literature review are presented below. This resulted in a co-citation analysis of 16 articles. The most cited articles are the papers published by Martinez and del Bosque (2013), Mandhachitara and Poolthong (2011), Choi and La (2013), Pérez and del Bosque (2015) and Pérez and del Bosque (2014).

The two identified clusters were based on a bibliometric co-citation and a traditional detailed content analysis of all the articles presented in each group. As this analysis's topic is pinpointed and the same discussed by all the authors, the papers were clustered build on their mediating variables. The articles were then classified into two distinct clusters: mediating effects related to consumer behavior and mediating effects related to the brand. A summary of the main contributions is presented below in each cluster according to their yearly chronological order. Moreover, it should be noted that all of the publications used the structural equation model except Liu et al., 2014, Chomvilailuka and Butcher (2014), who used regression analysis and $\mathrm{Li}$ et al.,(2019), who used an experimental study.

\section{Cluster 1: Mediating effects related to consumer behavior}

The articles within this research stream deal with consumer behavior's mediating variables and their 
prominent role in explaining the relationship between perceived CSR and customer loyalty.

One of the main contributions of the literature of CSR in general and its relationship with customer loyalty, in particular, is the publication of Martinez and del Bosque (2013). The authors presented trust, satisfaction, and customer identification with the company as mediators. Spanish hotel consumers confirm that socially responsible companies contribute to the trustworthiness, identification, and satisfaction toward these companies. However, corporate identity management is crucial for companies as perceived CSR indirectly impacts loyalty via those three mediators. In the same vein, Choi and La (2013) introduced customer trust as a mediating variable in examining perceived legal and ethical dimensions of CSR on customer satisfaction, trust, and loyalty after a service failure. The study was generalized to various service-types in the USA. Perceived CSR has a direct effect on loyalty and an indirect impact on loyalty through customer trust. Indeed, CSR is a vital component while restoring customer loyalty.

Moving to the shipping industry, Shin and Thai (2014) confirmed the positive impact of CSR's perceived ethical and environmental dimensions on customer satisfaction and then relationship maintenance and later customer loyalty. CSR reports are considered a powerful marketing tool in this service context that may lead to customer loyalty if the mediators are confirmed. In the same year, Pérez and del Bosque (2014) examined the topic through two paths for the Spanish banking service. First, the authors confirmed the positive impact of perceived CSR on customer-company identification, the company's emotions, and thus customer satisfaction. Second, the company's emotions in the first path positively impact the emotions derived from the service, which in turn positively impacts customer satisfaction. Subsequently, in both ways, customer satisfaction influences behavioral loyalty.

One year later, Pérez and del Bosque (2015) examined the impact of three CSR components related to employees, society, and customers on savings and commercial banks' customers' behavior in Spain.

Customer satisfaction was a critical variable for the relationship between CSR and loyalty with the company's type as a moderator. The findings confirmed that CSR image impacts customers' affective dimension (customer satisfaction and customercompany identification). Subsequently, through the affective dimension, the conative component is positively impacted (customer recommendation and repurchase behaviors). Regarding the customer dimension of CSR image, no difference exists between the two types of banks on the affective component. For the society and employees' dimension of CSR image, savings banks' customers respond positively. Further, the employee dimension is the least significant on the affective part for both banks' types. Another contribution is the vital significance of affective variables on customer repurchase for commercial than savings banks' customers.

Moreover, Yeh (2015) investigated the wealth management customers in Taiwan regarding the impact of CSR and service innovation on customer loyalty through three different mediators: customer advocacy, relationship value, and relationship quality. The findings revealed that CSR and service innovation positively impact customer advocacy. Subsequently, customer advocacy positively impacts relationship quality and value, which in turn leads to customer loyalty. From his side, Inoue et al. (2017) introduced the involvement and commitment of customers' Australian professional football team as mediators. It was found that involvement positively mediates the relationship between the two constructs. However, this relationship is significant but not robust. On the opposite, commitment negatively mediates the relationship between involvement and behavioral loyalty. In other words, customer commitment is rather beneficial in the long run (i.e., word of mouth) than in the short-run (instant product sales).

In 2018, Palacios-Florencio et al. presented trust as a critical determinant mediator. The survey on Spanish hotels guests shows that the more the company is committed to socially responsible activities, the greater is the customers' image toward those hotels. However, CSR significantly impacts trust, which in turn positively influences customers' image and loyalty.

Li et al. (2019) examined a different CSR plan area - the approach of renewing a company's CSR strategy. The case study of Starbucks in China was used to explore customer-company identification as a mediator and brand reputation as a moderator in the relationship between renewed CSR strategy and customer loyalty. The findings were different in terms of the brand's strength. For strong brands, CSR renewal strategy increases customer-company identification with a moderating role of brand reputation and improves customer loyalty. Quite the opposite for weak brands; not changing CSR actions positively impact customer loyalty. This is mainly due to the customers' perceptions of CSR activities. In fact, the CSR renewal plan is perceived as based on altruism for strong brands and based on self-interest for weak brands.

\section{Cluster 2: Mediating effects related to the brand}

The articles within this research stream deal with the brand's mediating variables and their central role in explaining the relationship between perceived CSR and customer loyalty. Liu et al. (2014) introduced 
brand preference as a mediator in Macau's casino industry. The findings revealed the perception of two CSR dimensions (stakeholders \& society) that positively impact customer loyalty through a partial mediation of brand preference. Furthermore, the stakeholder-oriented actions of CSR have a significant effect on customers' brand preferences. Another critical contribution related to the brand as a mediator is the perceived service quality. Mandhachitara and Poolthong (2011) confirmed the positive impact of this mediator in Thailand's retail banking sector. Also, the direct influence between CSR and behavioral loyalty does not exist.

Moreover, corporate image constitutes the central part of this cluster. The study on Taiwan's intercity bus sector performed by Chang and Yeh (2017) showed that CSR would have no direct impact on customer loyalty with the absence of a mediator. Accordingly, customer satisfaction and, more particularly, corporate image significantly and positively mediate the relationship between CSR and customer loyalty.

Similarly, Gürlek et al. (2017) examined corporate image mediation in independent Turkish hotels. Partial mediation is confirmed through corporate image. Consequently, CSR actions should be broadcasted through advertising tools such as the media to enhance customer loyalty via socially responsible activities. The last variable within this research stream is corporate reputation. Aramburu and Pescador (2017) validated its partial mediation in the banking industry of the Basque country. The moderation variable of the bank's type seems to have no impact on the mediation.

\section{FUTURE RESEARCH AGENDA}

To obtain an overview of the issues not addressed by the most influential papers of CSR's literature with customer loyalty, a review of the 16 topcited papers was identified. In addition to the articles that create the citation map in Figure 4, the top ten of the most recent papers were also addressed.

The most important contributions of the first, second, and no cluster with a score of at least ten global citations (GCS $\geqslant 10$ ) published between 2011-2019 were identified respectively in Table3, Table 4, and Table 5.

Furthermore, the ten emerging articles published in 2020, receiving few or no citations were also depicted and presented in Table 6. 
Table 3: Cluster I- Future research questions

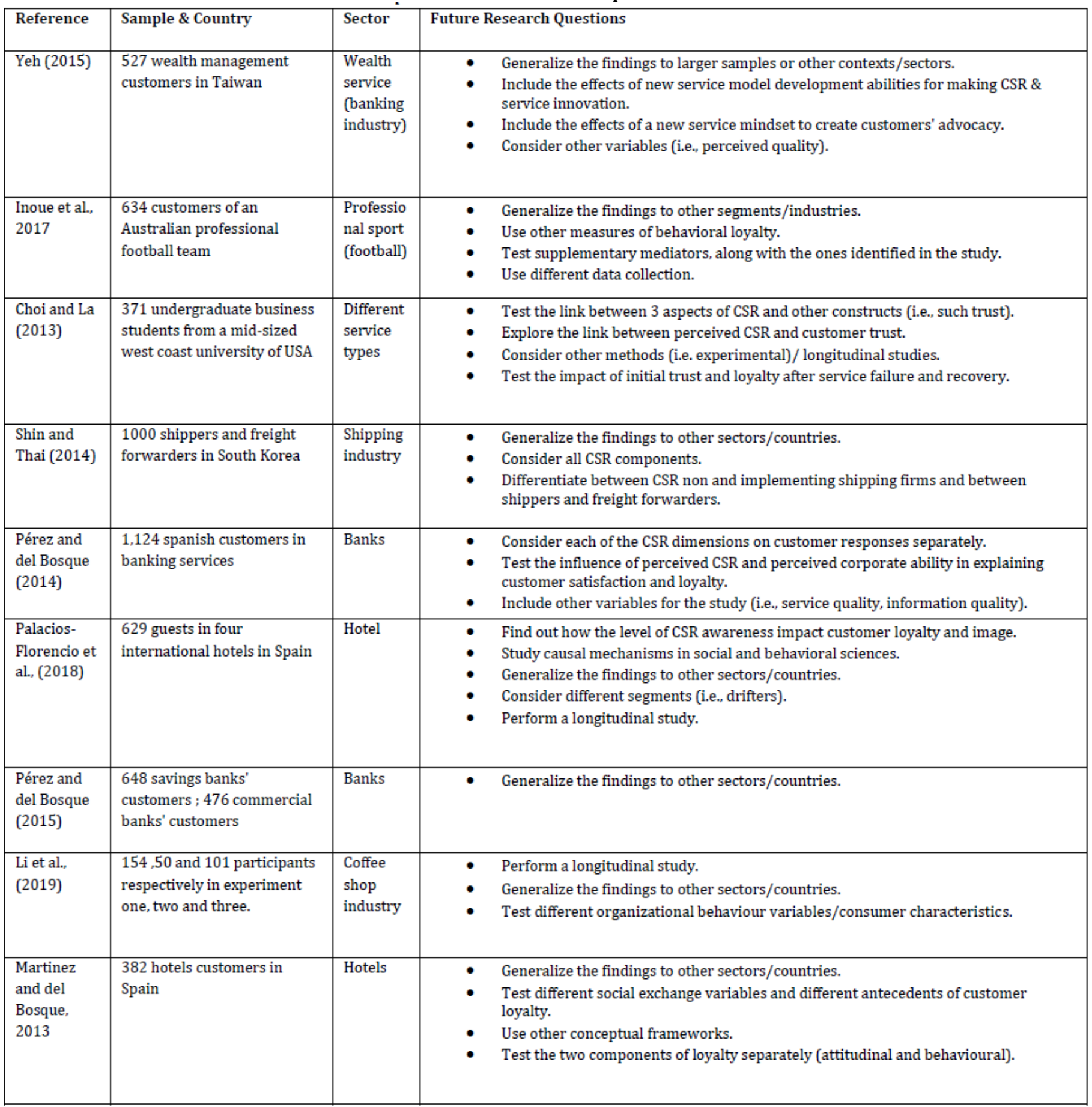


Table 4: Cluster II-Future research questions

\begin{tabular}{|c|c|c|c|}
\hline Reference & Sample \& Country & Sector & Future Research Questions \\
\hline $\begin{array}{l}\text { Mandhachit } \\
\text { ara and } \\
\text { Poolthong } \\
\text { (2011) }\end{array}$ & $\begin{array}{l}275 \text { bank customers in } \\
\text { Thailand }\end{array}$ & Bank & $\begin{array}{l}\text { - Test the proposed relationship model using other loyalty measurements tool. } \\
\text { - Test other mediators (trust, satisfaction, commitment). }\end{array}$ \\
\hline $\begin{array}{l}\text { Liu et al., } \\
2014\end{array}$ & $\begin{array}{l}616 \text { among casinos players in } \\
\text { China }\end{array}$ & Casino & $\begin{array}{l}\text { - Use a sample of six major casinos that represent traditional and integrated casinos. } \\
\text { - Generalize the findings to other hospitality firms / industries/cultures. } \\
\text { - Expand the model and include new variables. }\end{array}$ \\
\hline $\begin{array}{l}\text { Aramburu } \\
\text { and } \\
\text { Pescador } \\
\text { (2017) }\end{array}$ & $\begin{array}{l}572 \text { personal surveys in the } \\
\text { Basque country }\end{array}$ & Bank & $\begin{array}{l}\text { - Test the impact of specific component related to corporate reputation on customer } \\
\text { responses. } \\
\text { - Perform a longitudinal study. } \\
\text { - } \text { serform a qualitative study in explaining the link between attitudinal loyalty and } \\
\text { - Generalize the findings to other countries. }\end{array}$ \\
\hline $\begin{array}{l}\text { Chang and } \\
\text { Yeh (2017) }\end{array}$ & $\begin{array}{l}349 \text { customers of bus } \\
\text { services in Taiwan }\end{array}$ & $\begin{array}{l}\text { Bus } \\
\text { services }\end{array}$ & $\begin{array}{l}\text { - } \quad \text { Generalize the findings to other sectors. } \\
\text { Study the impact of CSR on customer loyalty in different transport modes and } \\
\text { passenger groups. }\end{array}$ \\
\hline $\begin{array}{l}\text { Gürlek et } \\
\text { al.,(2017) }\end{array}$ & $\begin{array}{l}404 \text { of hotels customers in } \\
\text { Turkey }\end{array}$ & Hotel & $\begin{array}{l}\text { - Generalize the findings to larger samples and other independent hospitality firms. } \\
\text { - Use public relations tools such as corporate advertising could be used as mediators } \\
\text { between CSR and corporate image. } \\
\text { - Use customer satisfaction as a mediator between corporate image and customer } \\
\text { loyalty. } \\
\text { - Use moderators such as the type of customer and the nationality. }\end{array}$ \\
\hline
\end{tabular}

Table 5: No Cluster-Future research questions

\begin{tabular}{|l|l|l|l|}
\hline Reference & Sample \& Country & Sector & Future Research Questions \\
\hline $\begin{array}{l}\text { Azmat and Ha } \\
(2013)\end{array}$ & $\begin{array}{l}\text { No sample \& case study of } \\
\text { Bangladesh }\end{array}$ & $\begin{array}{l}\text { Food } \\
\text { Supply } \\
\text { chain }\end{array}$ & - Check the conceptual model. \\
\hline $\begin{array}{l}\text { Chomvilailuka } \\
\text { and Butcher } \\
(2014)\end{array}$ & $\begin{array}{l}\text { Australia } \\
\text { Anst different CSR dimensions. }\end{array}$ & Banks & $\bullet \quad$ Generalize the findings to more significant samples \\
\hline
\end{tabular}


Table 6: Recent papers -Future research questions

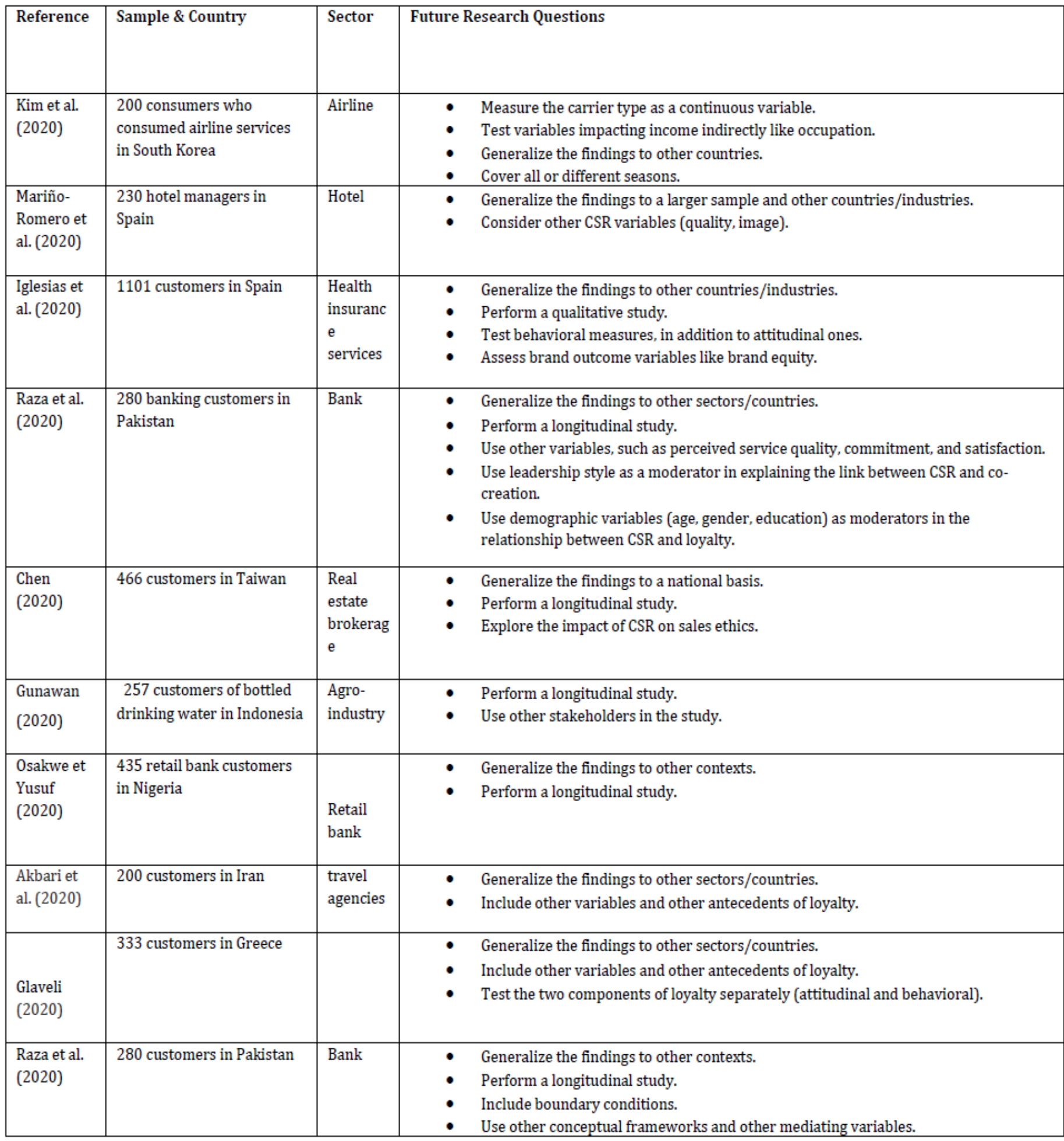




\section{DISCUSSION \& CONCLUSION}

The journals with the highest citations and publications in the field are social responsibility journal, journal of business ethics, journal of services marketing, corporate social responsibility, and environmental management.

In addition to developed countries, developing nations started to give importance to the topic, which shows the rise of customers' awareness in CSR and the

challenge for companies to establish a CSR strategy within their business core. The most influential articles were published in 2013 and 2015. The most cited articles are the papers published by Martinez and del Bosque (2013), Mandhachitara and Poolthong (2011), Choi and La (2013), Pérez and del Bosque (2015) and Pérez and del Bosque (2014). The peak in terms of publications was in 2017 and 2019, with 11 articles each year.

The quali-quantitative content analysis, combined with the citation analysis, revealed two distinct clusters based on their mediating variables: mediating effects related to the consumer behavior and mediating impact related to the brand. The cluster analysis showed that CSR's impact on customer loyalty is mainly explained indirectly through mediators except for Choi and $\mathrm{La}$ (2013), who confirmed the relationship directly and indirectly. As a matter of fact, CSR indirectly impacts customer loyalty through mediators that, without them, no link seems to exist. The indirect impact is explained through two degrees of mediation' strength: significant mediation and partial mediation. The significant mediation was confirmed by studies using trust, customer satisfaction, customer-company identification, relationship maintenance/value/quality, emotions, service quality, and corporate image as mediators. The partial mediation was affirmed in researches using corporate reputation/image and brand preference as mediators. The mediating effect of involvement was not robust, but still does exist. Besides, the mediating variables that were rejected are commitment and customer-company identification in the case of a CSR renewal strategy for weak brands. Moreover, this bibliometric study stresses the importance of services that have attracted more academic attention than tangible products. Thus, special attention needs to be deserved for products to widen knowledge.

The future research agenda was extracted from the most influential (2011-2019) and highest trending articles (2020). Future guidelines mainly emphasize generalizing the findings to other sectors, countries, or contexts. Also, the authors suggest performing a longitudinal study and testing other conceptual frameworks or other mediating variables.

This paper has a few limitations. This paper's analyses are based on WOS database, which does not include all the literature on the topic. Future researchers may use other databases like Scopus. Also, even though the bibliometric analysis is highly systematic, the research streams require a subjective method to review the literature through content analysis. Moreover, it is suggested for future academic researchers to perform a bibliometric analysis regarding the impact of CSR on consumer behavior in general and, in particular, for specific variables such as customer satisfaction.

However, and most importantly, it is hoped that the analyses put forward in this paper will contribute to advancing the existing knowledge and understanding the literature on the impact of CSR on customer loyalty.

\section{Conflict of interest}

The authors comply with ethical standards and declare that there is no conflict of interest.

\section{REFERENCES}

1. Edvardsson, B., Johnson, M. D., Gustafsson, A., Strandvik, T. (2000). The effects of satisfaction and loyalty on profits and growth: Products versus services. Total Quality Management, 11(7), 917927.

2. Sen, S., Bhattacharya, C. B., Korschun, D. (2006). The role of corporate social responsibility in strengthening multiple stakeholder relationships. Journal of Academy Marketing Science, 34(2), 158-166.

3. Palacios-Florencio, B., del Junco, J.C., Mario. J., Castellanos-Verdugo, M., Rosa-Díaz, I.M. (2018). Trust as mediator of corporate social responsibility, image, and loyalty in the hotel sector. Journal of Sustainable Tourism. 26, 1-17.

4. Lulewicz-Sas, A. (2017). Corporate Social Responsibility in the Light of Management Science - Bibliometric Analysis. Procedia Engineering 182, 412-417.

5. Ronda-Pupo, G.A., Guerras-Martin, L.A. (2012). Dynamics of the evolution of the strategy concept 1962-2008: a co-word analysis. Strategic Management Journal 33 (2), 162-188.

6. Azmat, F., Ha, H. (2013). Corporate Social Responsibility, Customer Trust, and LoyaltyPerspectives from a Developing Country. Thunderbird International Business Review. 55.

7. Martínez, P., Rodríguez-del-Bosque, I. (2013). CSR and customer loyalty: The roles of trust, customer identification with the company and satisfaction. International Journal of Hospitality Management. 35. 89-99. 
8. Yeh, Y. (2015). Corporate social responsibility and service innovation on customer loyalty: An empirical investigation in wealth management services. International Journal of Bank Marketing. 33. 823-839.

9. Inoue, Y., Funk, D., McDonald, H. (2017). Predicting behavioral loyalty through corporate social responsibility: The mediating role of involvement and commitment. Journal of Business Research. 75. 46-56.

10. Choi, B., La, S. (2013). The impact of corporate social responsibility (CSR) and customer trust on the restoration of loyalty after service failure and recovery. Journal of Services Marketing. 27.

11. Shin, Y., Thai, V.(2014). The Impact of Corporate Social Responsibility on Customer Satisfaction, Relationship Maintenance and Loyalty in the Shipping Industry. Corporate Social Responsibility and Environmental Management. 22.

12. Pérez, A., Rodríguez-del-Bosque, I. (2015). Corporate social responsibility and customer loyalty: Exploring the role of identification, satisfaction and type of company. Journal of Services Marketing. 29. 15-25.

13. Li, Y., Biqiang, L., Huan, T-C. (2019). Renewal or not? Consumer response to a renewed corporate social responsibility strategy: Evidence from the coffee shop industry. Tourism Management. 72. 170-179.

14. Pérez, A., Rodríguez-del-Bosque, I. (2014). An Integrative Framework to Understand How CSR Affects Customer Loyalty through Identification, Emotions and Satisfaction. Journal of Business Ethics. 129.

15. Mandhachitara, R.,Poolthong, Y. (2011). A model of customer loyalty and corporate social responsibility. Journal of Services Marketing. 25. 122-133.

16. Liu, M., Wong, I., Chu, R., Tseng, T-H. (2014). Do perceived CSR initiatives enhance customer preference and loyalty in Casinos? International Journal of Contemporary Hospitality Management. 26. 1024-1045.

17. Gürlek, M., Duzgun, E., Uygur, S. (2017). How does corporate social responsibility create customer loyalty? The role of corporate image. Social Responsibility Journal. 13.

18. Chang, Y-H., Yeh, C-H. (2017). "Corporate social responsibility and customer loyalty in intercity bus services," Transport Policy, Elsevier, vol. 59(C), pages 38-45.

19. Chomvilailuk, R., Butcher, K. (2014). Effects of quality and corporate social responsibility on loyalty. Service Industries Journal. 34. 938-954.

20. Agirre, I., Pescador, I. (2019). The Effects of Corporate Social Responsibility on Customer Loyalty: The Mediating Effect of Reputation in Cooperative Banks Versus Commercial Banks in the Basque Country. Journal of Business Ethics. 154.
21. Kim, Y., Lee, S., Roh, T. (2020). Taking Another Look at Airline CSR: How Required CSR and Desired CSR Affect Customer Loyalty in the Airline Industry. Sustainability. 12 (10). 4281.

22. Marino-Romero, J.M., Hernandez-Mogollon, J.M., Campon-Cerro, A.M., Folgado-Fernandez, J.A. (2020).

Corporate Social Responsibility in Hotels: A Proposal of a Measurement of its Performance through Marketing Variables. SUSTAINABILITY. 12 (7). 296.

23. Iglesias, O., Markovic, S., Bagherzadeh, M., Singh, J.J. (2020). Co-creation: A Key Link Between Corporate Social Responsibility, Customer Trust, and Customer Loyalty.JOURNAL OF BUSINESS ETHICS. 163 (1): 151-166.

24. Raza, A., Saeed, A., Iqbal, M.K., Saeed, U.I. (2020). Linking Corporate Social Responsibility to Customer Loyalty through Co-Creation and Customer Company Identification: Exploring Sequential Mediation Mechanism SUSTAINABILITY. 12 (6): Art. No. 2525.

25. Chen, W.C., Hsieh, K.M., Lin, C.S., Lee, C.C., Yu, C. (2020). Relationships between sales ethics, corporate social responsibility, trust, attitude, and loyalty in the real estate brokerage industry. SOCIAL BEHAVIOR AND PERSONALITY. 48 (3): Art. No. e8004.

26. Gunawan, S., Budiarsi, S.Y., Hartini, S. (2020). Authenticity as a corporate social responsibility platform for building customer loyalty.COGENT BUSINESS \& MANAGEMENT. 7 (1): Art. No. 1775023.

27. Osakwe, C., Yusuf, T. (2020). CSR: a roadmap towards customer loyalty. Total Quality Management \& Business Excellence. 1-17. 10.

28. Akbari, M., Mehrali, M., SeyyedAmiri, N., Rezaei, N., Pourjam, A. (2020). Corporate social responsibility, customer loyalty and brand positioning. SOCIAL RESPONSIBILITY JOURNAL. 16 (5): 671-689.

29. Glaveli, N. (2020). Corporate social responsibility toward stakeholders and customer loyalty: investigating the roles of trust and customer identification with the company. Social Responsibility Journal. ahead-of-print.

30. Raza, A., Ra, R., Iqbal, M., Bhutta, U. (2020). An assessment of corporate social responsibility on customer company identification and loyalty in banking industry: a PLS-SEM analysis. Management Research Review. ahead-of-print. 